\title{
SUBJECT REVIEW: STRATEGIC LEADERSHIP STYLE: FROM THE BOTTOM TO THE TOP
}

\author{
PhD Nisreen Jasim Mohammed \& Assist. Instruct. Haider Fadhel Kadhem \\ Public Administration Department \\ College of Administration and Economics, University of Baghdad
}

DOI: $10.37648 / \mathrm{ijrssh} . v 10 \mathrm{i} 03.005$

Received:18 ${ }^{\text {th }}$ May, 2020; Accepted:08 ${ }^{\text {th }}$ June, 2020; Published: $28^{\text {th }}$ June,2020

\begin{abstract}
Having wise and rational leadership will prosper the future of any organization. Strategic leadership is one of the highest levels of managing styles that affects every part of the decision-making process in the organization.Strategic leadershiphas required special skills and unique capabilities in creating managerial and instructional decisions that drivesuccessfor the organization. This subject review concentrates onreviewing essential characteristics of strategic leadership style and their effects on overall employees and organizational performance in order to be aneffective leadership ideal. The strategic leadership style plays a critical role in choosing the right and suitable strategic alternatives due to owningacumen experience administratively and functionally. The motivational future direction of strategic leadership increases job satisfaction. The aim of this paper is to address the issue of confining strategic thinking to the highest levels of the organizationusually. The main concern of the subject review uncovers how leaders can create bottom-up communicating path to encourage employees to think rationally.
\end{abstract}

Key words: Strategic leadership style; employee satisfaction;rational decisions.

\section{INTRODUCTION}

Hambrick \&Finkelstein (1987) referred that the consolidation relationship between the favorable outcome of the organization and strategic choices rely primarily on the discretion degree holding by senior directors. In other words, when the discretion degree holding by senior directors is at a high level of authority, the alternatives of strategic decisions will impact overall outcomes of the organization (as cited in Gakenia et al., 2017:9).
Top managers attempt to influence their subordinates through encouraging them to their best effort to add value to the workplace and that would be a hard mission. Managers support their employees morally to accomplish intend aims of the organization through directing and advising. The kind of mangers' behaviors and attitudes lies on how managers can successfully address different circumstances through a function of the time and place characteristics (Azbari et al., 2015 :455).

Hambrick (2007) defined strategic leadership as "being concerned with the entire scope of activities and strategic choices of the individuals at the pinnacle of the 
organization" (Özera and Tinatepe, 2014:779). Meaning that strategic leadership is the way of accomplishing organizational aims though participating positive influence on employees' performance by having a clear understanding of future vision, drawing work directions, placing plans into practice, and empowering employees at different levels of management (Arikan and ENGINOĞLU, 2016:1-2).

Hitt et al. (2005) described that strategic leadership meaning capability of predicting, visualizing, empowering, and maintaining a high level of work flexibility in order to implement critical and core changes to strategic performance of the organization (25-26).

\section{LITERATURE REVIEW}

Schoemaker and Krupp (2015) classified the core of strategic leadership traits into six differentiate abilities that distinguish strategic leaders from others:

- The ability to anticipate external threats and internal weaknesses in order to face and struggle in opposition to competitors.

- The ability to think rationally by providing creative solutions for obstacles encountered by the organization.

- The ability to evolve hypotheses to deal with dynamic circumstances beyond the organization control created by the environment.

- The ability to generate and assess alternatives to shape and plan the future strategies of the organization.

- The ability to encourage the workforce to participate in organization's mission, vision, and core values.

- The ability to acquire knowledge through being more open to external environment rather than the internal environment (24).

Davies \& Davies (2006) clarified that guiding the organization through strategic leadership style leads to set a clear understanding of the definite orientation of the organization, put the plan strategy processes into practice, enable employees to participate in drafting and executing the strategy. That will create a cooperative atmosphere to alleviate restrictions regarding to perform daily tasks smoothly (121).

Hoskisson et al. (2004) noticed that pumping new blood for the organization can make a huge difference if the new manager or chief executive officer (CEO) has a strategic vision and forward-looking. For instance, Steve Jobs, a cofounder of Apple computers, was a good model of strategic leadership style by turning the poor condition of Apple around though his exceptional and outstanding opinions and ideas. When he became as alternative CEO to John Scully in 1997, he tried to encourage and support depressed employees by successfully recovering Apple value and reputation again. The charismatic and rational thinking of Steve Jobs saved Apple from facing bankruptcy (as cited in Redmond, $2013: 3$ ).

Wanasika (2008) illustrated that the style of strategic leadership differentiates by the ability to take real risks and quick steps to encounter and contain crises from the internal and external environment through his or her superior ability to anticipate future directions (Oladele et al., 2013: 56).

Kumar thought that if the strategic leaders who intend to affect his or her employees behavior and attitudes, they have to handle challenges and ambiguity at the workplace and guide employees through specific and clear instructions and directions. That can be done through encouraging and empowering team works to perform desirable and intended changes (2018:20). Thus, having an organization with a strategic management direction is core and curcial in order to gian a sustainable competitive advantage (Lear, $2012: 2$ )

Moreover, Korbi revealed core skills and abilities that leaders should possess if they want to change and evolve the way of accomplishing strategic gools (2015:13), see the figure (1). 


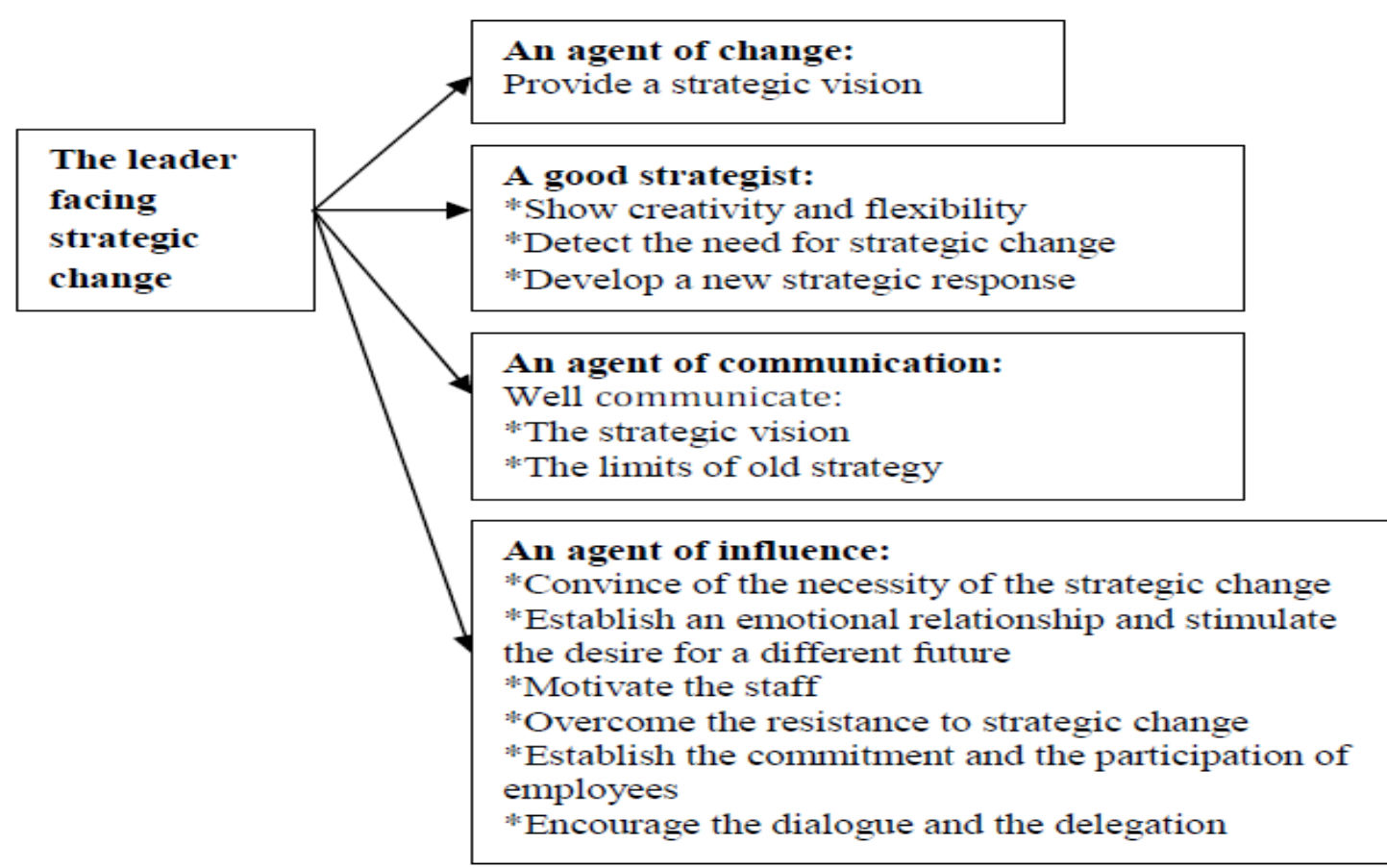

Figure (1) Skills of leader facing strategic chamge (Source: Korbi, Kaouther, (2015), Leadership and Strategic Change, The Journal of Organizational Management Studies, p.13).

If we take a close look at the figure (1), we can notice that the most effective skill and capability that a leader oughts to obtain is convincing employees to adopt strategic changes. From my point of view, employees who participate directly in regular meetings in order to discuss strategic changes and implement new job methods and developments are more willing to cooperate than others. In other words, employees who feel his or her suggestion is crucial to adopt new strategic changes will be encouraged to think creatively and rationally.

\section{CONCLUSION}

The successful and influential leadership style depends on how much space and freedom that employees have to explicit their suggestions, judgments, and opinions without being criticized and deterred. The strategic leadership style could spread the spirit of cooperation and synergies among employees by empowering competent employees to make necessary decisions. That will bring fundamental changes in the dynamics of the framework as well as enhance employee satisfaction and overall organizational performance through rational decisions.

Therefore, those who say that managing people through strategic approach is confined to senior management, is a wrong view because most of the important suggestions, ideas, and information come from the bottom up. Consequently, the organization must take into consideration that leadership style reflects the organization's reputation and its transparency towards its public and private audiences. For that reason, it is necessary to adopt the principle of partnership and cooperation within all levels of management in order to face external crises and internal administrative problems. That will make employee consider themselves as an integral part of the whole image of the organization. 


\section{REFERENCES}

1- Arikan, Cenk Laçin, and Didem ENGİNOĞLU, (2016), A CONTEMPORARY APPROACH TO STRATEGIC LEADERSHIP, International Journal of Information Technology and Business Management, Vol.47 No.1.

2- Azbari, Mostafa Ebrahimpour; Mohsen Akbari, and Milad Hooshmand Chaijani, (2015), The effect of strategic leadership and empowerment on job satisfaction of the employees of University of Guilan, International Journal of Organizational Leadership, Vol.4.

10- Davies, B. J., \& Davies, B. (2006). Developing a model for strategic leadership in schools. Educational Management,Administration, \& Leadership, 34(1).

3- Gakenia, Clare; Paul Katuse, and Peter Kiriri, (2017), Influence of Strategic Leadership Style on Academic Performance of National Schools in Kenya, Journal of Business and Management (JBM), Volume 19, Issue 7.

4- Hitt, Micheal. A., Ireland, R. Duaue, and Hoskisson, Robert. E. (2007). Strategic Management: Competitiveness and Globalization (Concepts and Cases) (7th ed.), Thomson South-Western.

5- Korbi, Kaouther, (2015), Leadership and Strategic Change, The Journal of Organizational Management Studies, Vol. 2015 .

6- Kumar, Sunil . R, (2018), LITERATURE REVIEW ON LEADERSHIP, LEADERSHIP THEORIES,STYLE AND LEADERSHIP DEVELOPMENT, International Journal of Research in Business Management ( IJRBM), Vol. 6 , Issue 6.

7- Lear, LORRAINE WENDY, (2012), The relationship between strategic leadership and strategic alignment in highperforming companies in South Africa, UNIVERSITY OF SOUTH AFRICA- GRADUATE SCHOOL OF BUSINESS LEADERSHIP (PhD dissertation).

8- Oladele, Olajide Patrick; Oluwafemi Adeusi; Niyi Israel Akeke, and Obawale Simeon Adebisi, (2013), Effects of strategic leadership styles on organizational development in small and medium enterprises (SMEs) in Lagos, Nigeria, Net Journal of Social Sciences Vol. 1(2).

9- Özera, Funda , and Cihan Tinaztepeb, (2014), Effect of Strategic Leadership Styles on Firm Performance: A study in a Turkish SME, 10th International Strategic Management Conference, Elsevier Ltd.

10- Redmond, James, (2013), STRATEGY AND THE IMPORTANCE OF STRATEGIC LEADERSHIP. Retrieved from http://www.bbc.com/capital/story/20131212-the-worst-ceos-of-2013.

11- Schoemaker, P. J. H., Krupp, S. (2015), Overcoming barriers to integrating strategy and leadership, Strategy \& Leadership, Vol. 43,No: 2. 